\title{
高強度短パルスレーザー駆動ナノ粒子クーロン爆発による 発生中性子数のレーザーエネルギー則
}

\author{
阪部 周二1,2, 橋田 昌樹1,2 \\ 1京都大学 化学研究所 先端ビームナノ科学センター（†611-0011 京都府宇治市五ヶ庄 $)$ \\ 2京都大学大学院 理学研究科物理学・宇宙物理学専攻 ( ⿳ 606-8502 京都市左京区北白川追分町)
}

\section{Laser-Energy Scaling Law for Neutrons Generated from Nano Particles Coulomb-Exploded by Intense Femtosecond Laser Pulses}

\author{
Shuji SAKABE ${ }^{1,2}$ and Masaki HASHIDA ${ }^{1,2}$ \\ ${ }^{1}$ Institute for Chemical Research, Kyoto University, Gokasho, Uji, Kyoto 611-0011 \\ ${ }^{2}$ Graduate School of Science, Kyoto University, Kitashirakawa-Oiwakecho, Sakyo-ku, Kyoto 606-8502
}

(Received September 1, 2014)

\begin{abstract}
To discuss the feasibility of compact neutron sources the yield of laser produced neutrons is scaled by the laser energy. High-energy ions are generated by Coulomb explosion of clusters through intense femtoseocnd laser- cluster interactions. The laser energy scaling law of the neutron yield is estimated using the laser intensity scaling law for the energy of ions emitted from clusters Coulomb-exploded by an intense laser pulse. The neutron yield for $D(D, n)$ He shows the potential of compact neutron sources with modern laser technology, and the yield for $\mathrm{p}(\mathrm{Li}, \mathrm{n})$ Be shows much higher than that for $\mathrm{Li}(\mathrm{p}, \mathrm{n}) \mathrm{Be}$ with the assumption of $500 \mathrm{~nm}$-class cluster Coulomb explosion.
\end{abstract}

Key Words: Neutrons, Intense femtosecond laser, Coulomb explosion, Clusters, Proton acceleration

\section{1.はじめに}

パルスレーザーを物質に集光照射することにより微小 高温プラズマを生成することができ，それより高エネル ギー放射線(電子，X線，イオン，光など)が発生する。 レーザーの発明後すぐにレーザープラズマの研究が行な われてきたが，放射線源としての実用的な視点での研究 は殆ど行なわれてこなかった。その主な理由は，例え ば，イオンの場合, 数百 $\mathrm{keV}$ 以上のエネルギーを得るに は， $10^{14} \mathrm{~W} / \mathrm{cm}^{2}$ 以上のレーザー強度が必要である ${ }^{1)}$ 。こ のような高強度を実現するには核融合研究用のような大 規模な大出力レーザー施設が必要となり，レーザープラ ズマイオン源は装置規模の観点からは従来の加速器など に比して特に優位ではなかった。

しかし，近年の極短パルスレーザー技術とCPA (Chirp Pulse Amplification) 概念を用いた高強度レーザー技術の 飛躍的な発展により，テーブルサイズの小型レーザーで も高強度を実現できるようになり，レーザー生成放射線 が注目されるようになってきた ${ }^{2)}$. 又, この10数年の間 に, レーザー生成高エネルギー放射線を利用した様々な 核反応も実証され (中性子発生, RI生成など) ${ }^{2)}, レ ー$ ザー生成放射線が次世代の放射線として研究の対象に
なっている。一般に，レーザー生成放射線は点源，パル ス，高輝度，異放射線間の完全同期，小型といった特徵 が上げられるが，応用によりそれぞれの特徵に優劣があ り，これらを吟味しなければならない。

中性子は強い物質透過力, 高い軽元素識別能力, スピ ンによる磁気散乱などの特徴を有しているので, 中性子 散乱, 中性子ラジオグラフィー, 即発ガンマ線分析, 中 性子捕捉療法などに利用でき, 科学, 医療, 産業の分野 での応用が期待されている。しかし，その線源には原子 炉や大型加速器を要し, 我が国でも, 原研, KEK, J-PARCなどの超大型施設での利用に限られており，中 性子利用科学の発展はまだ十分とはいえない，X線回 折 - 分光が広く普及しているのは，小型のX線分光装置 が利用できるため, Spring-8のような大型施設での研究 の実施までに，それらにより基礎，予備研究が十分に行 なえ，利用者にとってX線利用に対する障壁が低い為で ある。他方，中性子にはそのような小型装置がないた め，中性子利用が十分に普及しておらず，大型施設が完 成しても，利用者がまだ少ないのが現状である。このよ うな背景の中，小型中性子源の開発が望まれるが，従来 形では単に加速器を小さくするだけで，自ずとその限界 はある。 
レーザーにより中性子を発生するには，究極的には レーザー爆縮核融合やレーザー加速器が夫々, 現在の中 性子源に用いられている核分裂炉や加速器に代わりうる ものになる。しかし，レーザー物質相互作用で発する高 エネルギーイオンを中性子発生に利用することで，小 型, 中型の中性子源の可能性を議論することは, 上述の 中性子科学の普及という観点から意義のあることであ る.

高強度レーザーにより高エネルギー量子を発すること さえできれば，それを核反応 (核破砕，核融合)に利用で き, 中性子源のような2次放射線源になり得ることは誰 しも考えうることである。レーザー加速など高強度レー ザーを用いた量子ビーム生成の研究は世界の多くの研究 機関で活発に行われている。しかし，現状では量子ビー ムの到達エネルギーを競っており, その線量については レーザーや標的の諸元依存性の詳細は未だに明らかに なっていない段階である，例えば，照射面積は異なるが レーザー強度やレーザーパルス幅などのレーザー諸元が 全く同じ場合, 発生する量子線量は照射面積比になると 考えられるが，レーザー標的相互作用の物理からは必ず しも自明なことではない. 最近ではM. Rothらが, 重水 素を含む固体ターゲットからのレーザー加速重水素イオ ンを用いた $\mathrm{Be}(\mathrm{D}, \mathrm{n})$ よって $5 \times 10^{9}$ 個 $/ \mathrm{sr}$ の中性子発生を報 告しているが文，これから中性子数のレーザーエネル ギー則を導きだすにはまだ我々の知見は十分ではない。

本解説論文は，レーザー生成量子線を用いた中性子源 の線量の大まかなレーザーエネルギー比例則を示すこと で, 今後の関連研究やレーザー設計のための参照や指標 を提供することを目的としている。レーザーと物質(標 的)との相互作用の系は様々なものが考えられるが，こ こでは, 上述のような照射面積についての線量依存の不 確定が少ないであろうと考えられ，また実用の観点から も, 標的供給が比較的容易, 放射線管理区域の狭小化が 期待できるナノ粒子を標的とする系での中性子源を対象 としている.

T. Ditmireらの実験(重水素クラスターに高強度レー ザーを照射することにより中性子を発生) 以来 ${ }^{4-6)}$, 多く の研究グループがレーザーとクラスターとの相互作用の 研究を行なってきたが文, 特に, 筆者は, 高強度短パル スレーザーをクラスター分子に照射すると, 瞬時にクラ スターから電子が剥離され, 残されたイオンクラスター がそのクーロン反発力により爆発し, 高エネルギーイオ ンとなり飛散する(クーロン爆発), すなわち, クラス ターがマイクロプラズマとして膨張飛散するのではなく クーロン爆発することを実験的に初めて検証した7)。ま た，クラスター爆発生成イオンエネルギーのレーザー強 度比例則を示した。このような研究成果を基に, 本解説 論文では，レーザーとクラスター(ナノ粒子) との相互作 用により発生する高エネルギーイオンを利用した核反応 中性子のレーザーエネルギー比例則を議論し, 中性子源 の可能性を示す. 尚, 本論文の中心的な部分は参考文献 8)に掲載されている.

\section{2. レーザークラスター相互作用による 高エネルギーイオン発生}

ナノ秒パルスレーザーを固体に集光照射した場合の物 理過程の概略は次のようになる。レーザーパルスの前半 部分により固体表面が加熱 $\left(<10^{7} \mathrm{~W} / \mathrm{cm}^{2}\right)$ され, 液化 $\left(10^{6}\right.$ $\left.\sim 10^{9} \mathrm{~W} / \mathrm{cm}^{2}\right) \cdot$ 気化 $\left(\sim 10^{9} \mathrm{~W} / \mathrm{cm}^{2}\right)$ ・プラズマ化 $\left(>10^{10} \mathrm{~W} / \mathrm{cm}^{2}\right)$ とすすみ, 生成されたプラズマ中をレーザー光がカット オフ(共鳴)密度まで進みながら吸収されていく，吸収さ れたエネルギーは熱伝導や輻射により深部に(アブレー ション面まで)伝わり加熱される。加熱されたプラズマ は膨張により冷めていく，レーザーが照射されている間 はプラズマ温度できまる音速で等温膨張し，パルスが終 わると断熱膨張する。 この膨張をアブレーションと呼ぶ こともある。結果として, 吸収されたエネルギーが熱伝 導等により深部に伝わり, 液化蒸発に足る温度まで達し た領域が剥離される。このようなレーザープラズマ相互 作用の間にイオンが飛散する。つまり, 高温プラズマの 膨張過程がイオン発生になる。プラズマはその殆どの部 分は中性であるが，プラズマと真空の界面では中性が破 れている(デバイ長程度)。プラズマ中の高エネルギー電 子が界面から抜け出し, 重いイオンが残されそこに形成 されたシース電界によりイオンが加速される。よって, イオンのエネルギーはプラズマの電子温度で決まり，そ のエネルギー分布はMaxwell分布になる。最大エネル ギーは膨張先端のポテンシャル勾配(電界)の最大值で決 まり，電子温度の10倍程度になることが実験により確か められている ${ }^{1)}$. 高エネルギーイオンを発生するには, いかに瞬時に電子を高速に加速し，ポテンシャル勾配の 大きいシースを形成するかである。最近の高強度レー ザーと薄膜との相互作用による高エネルギーイオン発生 は基本的にはこの原理に基づいている. 高強度レーザー パルスのポンデロモーティブカにより電子を加速し, 残 されたイオンとの間に形成された急峻なポテンシャル勾 配によりイオンを加速する。（レーザーによる陽子加速 に関する参考文献は多いため, ここでは本会誌解説論文 の11）を引用しておくので，その論文の参考文献を参照）

しかし，孤立した微小固体から瞬時に多くの電子を剥 離することができれば，飛散するイオンのエネルギー分 布は異なる. 残されたイオン間のクーロン反発力により イオンが加速される. しかも, 初期のイオンが最も多い 状態で, 外側のイオンが最大の加速を受け, 残るイオン 数が減じるに従ってイオンエネルギーは小さくなる. よって, イオンのエネルギー分布は右肩あがりの分布に なり, 最大エネルギーをもつ。このようなクーロン反発 力による加速はレーザーの波長に比べて十分小さい固体 標的の場合に実現できる.

球状プラズマから瞬時に電子が取り除かれたイオンの

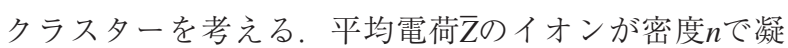
集した半径Rのイオンクラスターの場合，クーロン反発 力によりイオンが飛散する(クーロン爆発)。このとき, 飛び出した電荷Zのイオンの最大エネルギーとエネル ギー分布は次のようになる,12). 

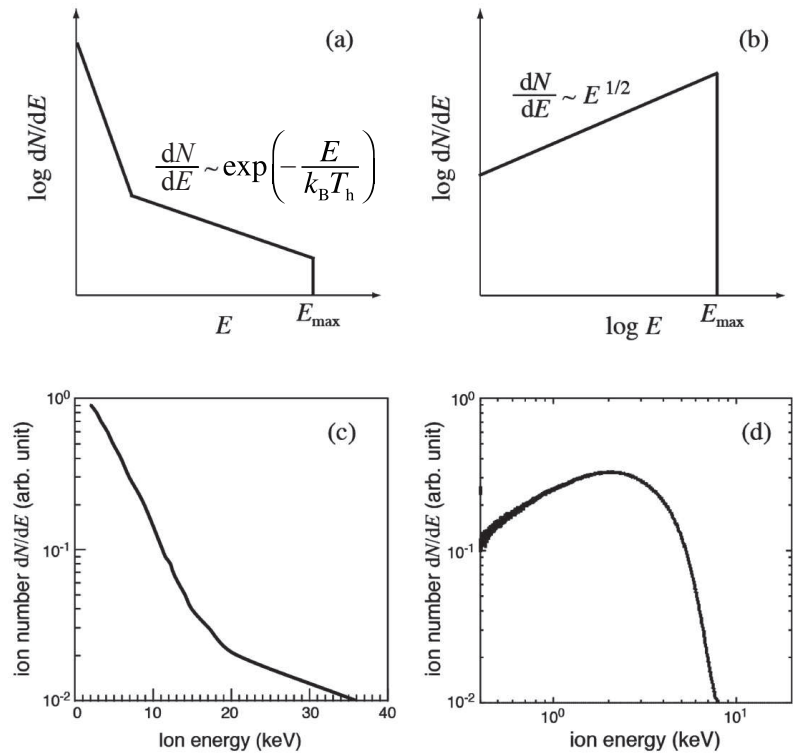

Fig. 1 Energy distributions (analytical model) of ions emitted from (a) an expanding plasma and (b) a Coulomb-exploded spherical cluster. Energy distributions (experimental results) of ions emitted from (c) argon clusters irradiated by $300 \mathrm{ps}$ laser pulses $^{10)}$ and (d) hydrogen clusters by $100 \mathrm{fs}$.

$$
E_{\max }=\frac{4}{3} \pi Z^{2} e^{2} n R^{2} \cong 300 Z \bar{Z}\left(\frac{n\left[\mathrm{~cm}^{-3}\right]}{5 \times 10^{22}}\right)(R[\mu \mathrm{m}])^{2}[\mathrm{MeV}](1)
$$

$$
\frac{d N}{d E}=\frac{3}{4 Z \bar{Z} e^{2}} \sqrt{\frac{3 E}{\pi n}}
$$

上述のナノ秒レーザープラズマ膨張(あるいはフェムト 秒レーザーの薄膜へ照射)で得られるイオンの場合とと もに，それぞれのエネルギー分布の概略をFig. 1 (a) (b) に示す.

実際に，クラスターに高強度レーザーを照射した場 合, 生成されるマイクロ球状プラズマがクーロン爆発を 起こしているのか. それとも，単に熱膨張しているのか を，筆者らは実験により検証している。これらの直接的 な観測は困難であるが, 飛散するイオンのエネルギー分 布を調べれば明らかである。実験では，高圧の水素やア ルゴンを電磁バルブを介して真空中に噴出することによ る断熱膨張により冷却し，クラスターを生成した。クラ スターに100 fs， $800 \mathrm{~nm}$ のレーザーを集光照射し，飛散 イオンのエネルギーを飛行時間型分析器により測定し $た^{7-10)}$. Fig. 1 (d) は，水素クラスター実験で得られたイ オンエネルギー分布である。明らかに, $d N / d E \propto \exp$ $(-E)$ ではない最大エネルギーをもつ $d N / d E \propto \sqrt{E}$ 型の分 布をもっている。（Fig. 1 (d)の分布がFig. 1 (b)のように 明瞭な最大值を示していないのは，照射領域内にあるク ラスターの大きさに分布があるためである。）しかし，パ ルス幅を広げ尖塔強度を下げた場合，瞬時のクラスター イオン化ができず，クラスター全体が温まり膨張すると 考えられる。実際，アルゴンクラスターの実験である が，長パルスではFig. 1 (c)のように, $d N / d E \propto \exp (-E)$

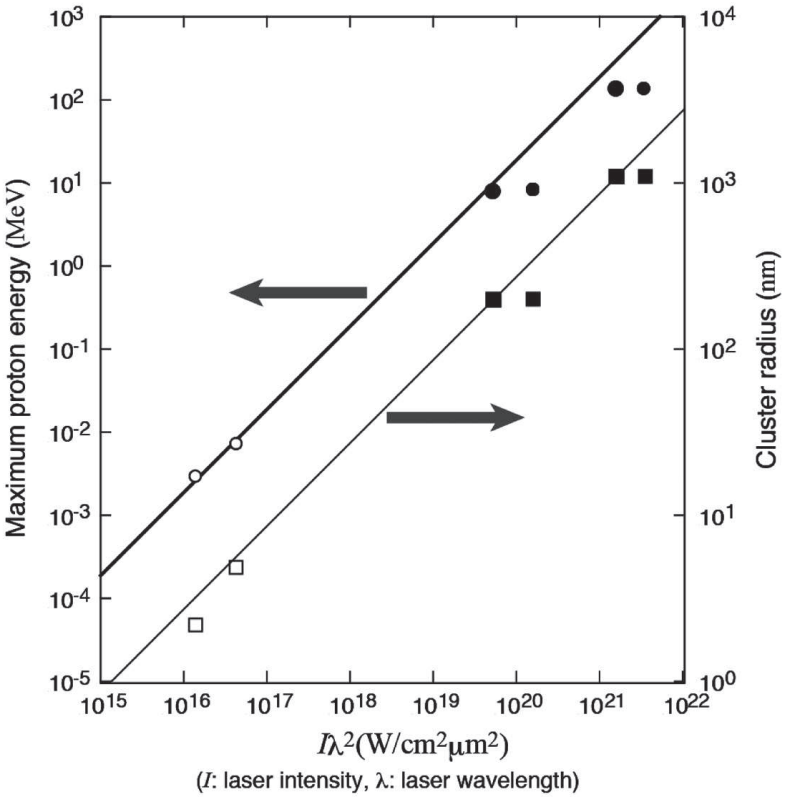

Fig. 2 Maximum proton energy and cluster size for the laser intensity given by a uniform spherical cluster analytical model. The open and closed symbols are the experimental results and the three dimensional PIC simulation results.

の分布になっている。これらの実験結果から，高強度極 短パルス照射下ではクラスターが膨張ではなく爆発して いると結論するのが妥当である。ささに，他にも次のよ うな実験結果が得られている ${ }^{10)}$ （1）放射イオンの最大 エネルギーのレーザー強度依存性：あるレーザー強度以 上ではイオンのエネルギーは増加していない(参考文献 (10)のFig. 4)。 マイクロプラズマ膨張の場合, レーザー 強度の増加に伴い電子温度が上昇し, 膨張イオンのエネ ルギーは増加する。他方，イオンクラスターのクーロン 爆発では，爆発イオンエネルギーはクラスターの大きさ で決まるので，レーザー強度に依存しなくなる。（2）放 射イオンのガス背圧 (クラスターの大きさ) 依存性 : 大き いクラスターほどイオンのエネルギーが大きくなってい る(参考文献 (9) のFig. 2，（10）のFig. 2)。マイクロプラ ズマ澎張の場合，イオンエネルギーはプラズマに吸収さ れたエネルギーが同じである限り，プラズマの大きさに 依存しない，イオンクラスターでは，クラスターが大き い程，大きな爆発エネルギーを与える。これらの全ての 結果は, クラスターがマイクロプラズマ膨張しているの ではなく，クラスターから電子が剥ぎ取られイオンクラス ターとなりクーロン爆発していることを結論付けている.

\section{3. クラスタークーロン爆発による発生イオン エネルギーのレーザー強度比例則}

上述のようにクラスターのクーロン爆発では飛散する イオンのエネルギーはクラスターの大きさで決まる。 よって，レーザー強度依存はイオンクラスター生成過程 に現われる。簡単な電磁気計算により，半径 $R$ の球状プ ラズマから，電子を剥ぎ取るのに必用なレーザー強度 は9,12) 


$$
a_{0}>\left(\frac{8 \pi Z e^{2} n}{3 m c^{2}}\right)^{1 / 2} \cong 34\left(\frac{\bar{Z} n\left[\mathrm{~cm}^{-3}\right]}{5 \times 10^{22}}\right)^{1 / 2}(R[\mu \mathrm{m}])
$$

となる。ここで， $a_{0}$ は規格化ベクトルポテンシャルで, レーザー強度 $I_{\mathrm{L}}$ との関係は

$$
a_{0}=\left(\frac{I_{\mathrm{L}}\left[\mathrm{W} / \mathrm{cm}^{2}\right]}{1.37 \times 10^{18}}\left(\lambda_{\mathrm{L}}[\mu \mathrm{m}]\right)^{2}\right)^{1 / 2}
$$

これより，電子を剥ぎ取れるクラスターの大きさと，そ のイオンクラスターのクーロン懪発により発するイオン の最大エネルギーのレーザー強度依存性は, 次のように なる。

$$
\begin{gathered}
R=\frac{25}{\bar{Z}}\left(\frac{\bar{Z} n\left[\mathrm{~cm}^{-3}\right]}{5 \times 10^{22}}\right)^{-1 / 2}\left[\frac{I_{\mathrm{L}}\left[\mathrm{W} / \mathrm{cm}^{2}\right]}{10^{18}}\left(\lambda_{\mathrm{L}}[\mu \mathrm{m}]\right)^{2}\right]^{1 / 2}[\mathrm{~nm}] \\
E_{\max }=0.19 Z \frac{I_{\mathrm{L}}\left[\mathrm{W} / \mathrm{cm}^{2}\right]}{10^{18}}\left(\lambda_{\mathrm{L}}[\mu \mathrm{m}]\right)^{2}[\mathrm{MeV}]
\end{gathered}
$$

Fig. 2は水素クラスターの場合 $(\bar{Z}=Z=1)$ のイオンエ ネルギーとクラスター大きさのレーザー強度依存性を示 す。これに，筆者の実験結果 ${ }^{9}$ ) と西原らのPIC (Particlein-Cell) シミュレーションの結果 ${ }^{12)}$ を合わせて示す.上 述のレーザー強度比例則が妥当であることが示されてい る.

\section{4. レーザーナノ粒子相互作用による中性子発生}

T. Ditmireらが最初にレーザークラスター相互作用に より中性子発生を実証したのは, 重水素クラスターを用 いてである ${ }^{4-6)}$. 恐らく, クーロン爆発により飛散した 重水素イオンが他の飛散イオンあるいは背景にある重水 素ガスと核反応した結果である。ここでは, 高エネル ギーイオンをクラスターの爆発により発し, その周辺に 配置した標的(固体(気体)) に衝突させることを想定す る. 次の 2 つの応を考える.

(a) $\mathrm{D}+\mathrm{D} \rightarrow \mathrm{He}^{3}+\mathrm{n}(2.45 \mathrm{MeV})$

(b) $\mathrm{p}+\mathrm{Li}^{7} \rightarrow \mathrm{Be}^{7}+\mathrm{n}-1.6 \mathrm{MeV}$

(a) は比較的小さいエネルギーの重水素イオンでも反応 するので，小型のレーザーの可能性がある，しかし，発 生中性子のエネルギーは大きく, 冷中性子への減速材や 遮蔽材が大きくなる。（b)では，反応のしきい值が $2 \mathrm{MeV}$ 程度であるので，それを越えるエネルギーの陽子 を必要とする反面, 発生中性子のエネルギーは数百 $\mathrm{keV}$ に抢さえることができ, 減速材, 遮蔽材への要請を緩和 できる.

イオン源として, $\mathrm{p}(2.25 \mathrm{MeV}), \mathrm{D}(100 \mathrm{keV}), \mathrm{D}(2 \mathrm{MeV})$ を考える. $\mathrm{p}(2.25 \mathrm{MeV})$ と $\mathrm{D}(2 \mathrm{MeV})$ は核反応断面積が 最大となるエネルギーである。まず, $2.25 \mathrm{MeV}$ の陽子 を作るには, Fig. 2から, 約 172 nm径のクラスターが必 要である。このような大きさのクラスターは上述の実験 の方法では作る事ができない，ここでは，技術的な手法

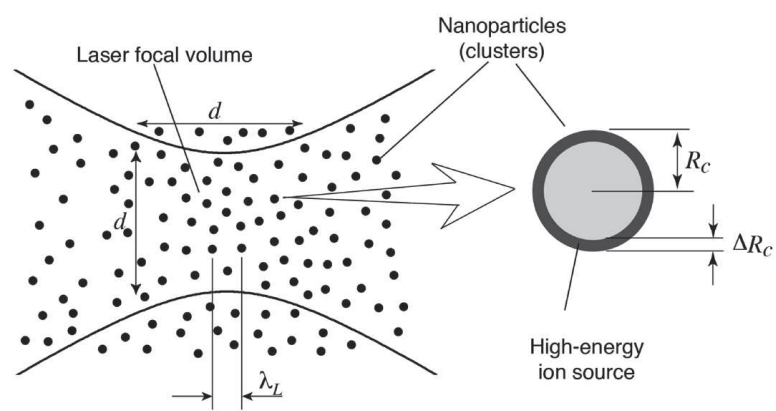

Fig. 3 Conceptual system of laser irradiation into cluster gas and high-energy ion source of the cluster.

に付いては言及しないが，Fig. 3のようにナノ粒子を レーザー波長 $\left(\lambda_{\mathrm{L}}\right)$ 程度の間隔を置いて配した(平均間隔 であり，整然と並べる必要はない)ターゲットを考え る. 最大エネルギー $E_{\text {max }}\left(\right.$ エネルギー幅 $\left.\Delta E_{\max }\right)$ の平均密度 は

$$
n_{\mathrm{p}}=n_{\mathrm{s}} \frac{4 \pi R_{\mathrm{c}}^{2} \Delta R_{\mathrm{c}}}{\frac{4}{3} \pi R_{\mathrm{c}}^{3}}\left(\frac{R_{\mathrm{c}}}{\lambda_{\mathrm{L}}}\right)^{3}=n_{\mathrm{s}} \frac{3 \Delta E_{\max }}{2 E_{\max }}\left(\frac{R_{\mathrm{c}}}{\lambda_{\mathrm{L}}}\right)^{3}
$$

ここで, $n_{\mathrm{s}}$ はナノ粒子の密度 (固体密度),$R_{\mathrm{c}}$ はクラス ター半径, $\Delta R_{\mathrm{c}}$ は対象としている発生イオンとなるクラ スター外殼の厚みである。レーザーの集光径を $d$, 集光 長も同程度の $d$ (イオンの発生領域を直径, 高さ $d$ の円柱) と仮定すると, 発生中性子数は

$$
N_{\mathrm{n}}=n_{\mathrm{p}} \pi\left(\frac{d}{2}\right)^{2} d n_{\mathrm{Li}} \int_{0}^{R(E)} \sigma(E) d z=\frac{\pi}{4} d^{3} n_{\mathrm{p}} n_{\mathrm{Li}} \int_{0}^{R(E)} \sigma(E) d z
$$

となる。ここで， $n_{\mathrm{Li}}$ は標的の $\mathrm{Li} の$ 密度， $\sigma$ は核反応断面 積, $z$ は陽子の標的中での平均飛程距離, $R(E)$ は標的物 質中での阻止能である。レーザーパルス幅を $\tau_{\mathrm{L}}$ とする と, レーザー強度 $I_{\mathrm{L}}$ とレーザーエネルギー $E_{\mathrm{L}}$ の関倸

$$
I_{\mathrm{L}}=\frac{P_{\mathrm{L}}}{\pi(d / 2)^{2}}=\frac{4 P_{\mathrm{L}}}{\pi d^{2}}=\frac{4 E_{\mathrm{L}}}{\pi d^{2} \tau_{\mathrm{L}}}
$$

より，レーザー集光径をレーザーエネルギーで表し，発 生中性子数に代入すると,

$$
\begin{aligned}
& N_{\mathrm{n}}=\frac{2}{\pi^{1 / 2}}\left(\frac{E_{\mathrm{L}}}{I_{\mathrm{L}} \tau_{\mathrm{L}}}\right)^{3 / 2} n_{\mathrm{p}} n_{\mathrm{L}} \int_{0}^{R(E)} \sigma(E) d z \\
& =\frac{2}{\pi^{1 / 2}} \frac{n_{\mathrm{p}} n_{\mathrm{Li}}}{\left(I_{\mathrm{L}} \tau_{\mathrm{L}}\right)^{3 / 2}} \int_{0}^{R(E)} \sigma(E) d z \cdot E_{\mathrm{L}}^{3 / 2}
\end{aligned}
$$

が得られる。

\section{5. 発生中性子のレーザーエネルギー比例則}

上述の発生中性子のレーザーエネルギー依存の式を用 いて, $\mathrm{p}(2.25 \mathrm{MeV}), \mathrm{D}(100 \mathrm{keV}), \mathrm{D}(2 \mathrm{MeV})$ のイオン 源の場合を考える。これらのエネルギーのイオンを生成 するのに必要なレーザー強度とクラスターの大きさを, 主な定数とともにTable 1に示す。その結果， 
Table 1 Parameter, optimized cluster diameters and laser intensities for the calculation of laser-energy scaling of neutron yields from Coulomb-exploded clusters.

\begin{tabular}{ccccc}
\hline Reactions & ${ }^{7} \mathrm{Li}(\mathrm{p}, \mathrm{n})^{7} \mathrm{Be}$ & $\mathrm{D}(\mathrm{D}, \mathrm{n})^{3} \mathrm{He}$ & $\mathrm{D}(\mathrm{D}, \mathrm{n})^{3} \mathrm{He}$ & ${ }^{7} \mathrm{Li}(\mathrm{p}, \mathrm{n})^{7} \mathrm{Be}$ \\
\hline \hline Collision energy & $2.25 \mathrm{MeV}$ & $100 \mathrm{keV}$ & $2 \mathrm{MeV}$ & $2.25 \times 7 \mathrm{MeV}$ \\
Laser intensity & $1.9 \times 10^{19} \mathrm{~W} / \mathrm{cm}^{2}$ & $8.2 \times 10^{17} \mathrm{~W} / \mathrm{cm}^{2}$ & $1.6 \times 10^{19} \mathrm{~W} / \mathrm{cm}^{2}$ & $1.3 \times 10^{20} \mathrm{~W} / \mathrm{cm}^{2}$ \\
Cluster & $172 \mathrm{~nm}$ & $36 \mathrm{~nm}$ & $162 \mathrm{~nm}$ & $455 \mathrm{~nm}$ \\
Reaction cross section & $0.5 \mathrm{barn}$ & $15 \mathrm{mbarn}$ & $90 \mathrm{mbarn}$ & $1.5 \mathrm{barn}$ \\
\hline Neutron yield & $2.1 \times 10^{6} E_{\mathrm{L}}^{3 / 2}$ & $3.4 \times 10^{5} E_{\mathrm{L}}^{3 / 2}$ & $2.1 \times 10^{8} E_{\mathrm{L}}^{3 / 2}$ & $2.2 \times 10^{9} E_{\mathrm{L}}^{3 / 2}$ \\
\hline
\end{tabular}

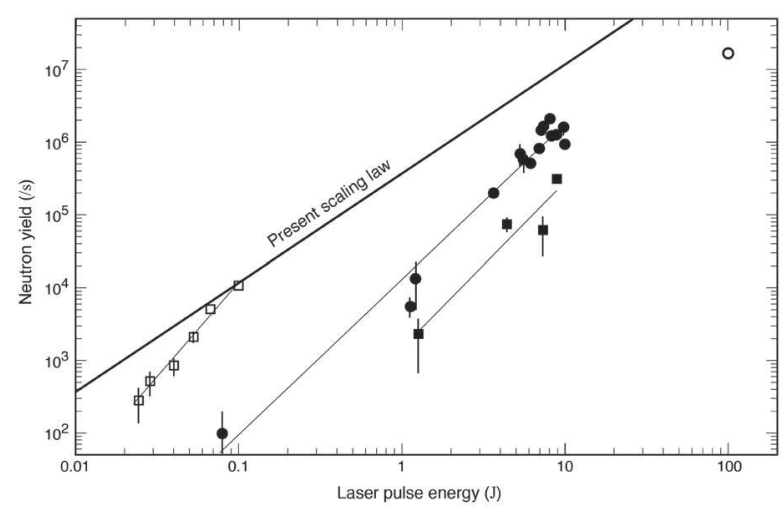

Fig. 4 Neutron yields from deuterium clusters for the experimental results $\left(\square^{13)}, \square \bigcirc^{14)}, \bigcirc^{15)}\right)$ and the present model for the reactions of $\mathrm{D}(\mathrm{D}, \mathrm{n}) \mathrm{He}$ $(\mathrm{D}=100 \mathrm{keV})$.

$\operatorname{Li}(\mathrm{p}, \mathrm{n}) \mathrm{Be}(\mathrm{p}=2.25 \mathrm{MeV}): \quad N_{\mathrm{n}}=2.1 \times 10^{6} E_{\mathrm{L}}^{3 / 2}$

$\mathrm{D}(\mathrm{D}, \mathrm{n}) \mathrm{He}(\mathrm{D}=100 \mathrm{keV}): \quad N_{\mathrm{n}}=3.4 \times 10^{5} E_{\mathrm{L}}^{3 / 2}$

$\mathrm{D}(\mathrm{D}, \mathrm{n}) \mathrm{He}(\mathrm{D}=2 \mathrm{MeV}): \quad N_{\mathrm{n}}=2.1 \times 10^{8} E_{\mathrm{L}}^{3 / 2}$

の発生中性子数のレーザーエネルギー則が得られる。計 算では $\Delta E_{\max } / E_{\max }=0.1$ とした. クラスターとの相互作用 により中性子を発生した実験と本比例則を比較してみ る. $\mathrm{D}(\mathrm{D}, \mathrm{n}) \mathrm{He}(\mathrm{D}=100 \mathrm{keV})$ の比例則と現在報告のある 中性子数のレーザーエネルギー依存性をFig. 4に示 $す^{13-15)}$.2つの文献の依存性は異なる。 また, 上述で得 られたレーザーエネルギー比例則と比較すると, 依存性 は異なるが，それぞれの上限を与えている事が分かる。 これは，本論文での議論にあるように，イオンのエネル ギーはクラスターの大きさで決まり, レーザー強度では 決まらない，レーザー強度を変えるとクラスターのイオ ン化の程度は変わるが, 最大エネルギーは変わらない.

実験ではレーザーのエネルギーの変化に伴いレーザー強 度も変化している。実験は, 必ずしもクラスター径や強 度を最適化したものではないためと考える. 本論文の比 例則はレーザー強度を一定にし，レーザーエネルギーの 増加とともに, 集光径を大きくし, 発生中性子数を増や している。よって，依存性が異なるのは明らかである。 しかし，この比例則は発生中性子の上限を与えるものと して有益である。

ここで, $\operatorname{Li}(\mathrm{p}, \mathrm{n}) \mathrm{Be}(\mathrm{p}=2.25 \mathrm{MeV})$ ではなく, $\mathrm{p}(\mathrm{Li}, \mathrm{n})$ $\mathrm{Be}(\mathrm{Li}=2.25 \times 7 \mathrm{MeV})$ を検討してみる，つまり， Liを含 むナノ粒子をクーロン爆発させ $2.25 \times 7 \mathrm{MeV}$ の Liイオン を発生し, 周辺の水素ガスに衝突させ, 核反応を起こさ せるものである。この場合，レーザーの強度は
$1.3 \times 10^{20} \mathrm{~W} / \mathrm{cm}^{2}$ と高くなり, 必要なナノ粒子の直径も $455 \mathrm{~nm}$ になる。このような大きなナノ粒子を波長間隔 に位置した場合も，上述と同様の相互作用が起こると仮 定すると，レーザーエネルギー則は $N_{\mathrm{n}}=2.2 \times 10^{9} E_{\mathrm{L}}^{3 / 2}$ と なり極めて高い中性子数を示す(この場合の計算ではナ ノ粒子の径が大きいので，中心間隔を波長とせず，間隔 を波長としている)。これは, ナノ粒子が大きくなるこ とによるイオン数の増大と周辺の水素が気体であるた め, 阻止レンジが長くなり, 標的水素数が増えることに よる。ただし，このような系(大きなナノ粒子を波長間 隔で配置)でも同様な相互作用, クーロン爆発が起こる かの基礎実験による検証は必要である。

\section{6. 中性子源への可能性と特徵}

本論文で得た発生中性子数のレーザーエネルギー依存 性を用いて，中性子源の可能性を検討してみる。例え ば，産業応用の一つとして構造物の非破壊検査へ利用可 能な小型中性子源として $10^{11}$ 個/s以上を想定する。 Fig. 5 (a) $\mathrm{Li}(\mathrm{p}, \mathrm{n}) \mathrm{Be}(\mathrm{p}=2.2 \mathrm{MeV})$ 反応を用いた場合の中性 子数とレーザーエネルギーの関係を示している. $1 \mathrm{~kJ} /$ $1 \mathrm{~Hz}$ のレーザーをもつことができれば, 可能であるが, このレーザーが従来の加速器ベースのイオン源と比べて 小型かという議論は残る。ただし, 発生中性子のエネル ギーは数百 $\mathrm{keV} に$ 抑えられるので, 減速材を小型化にで きる。また，レーザー装置施設を放射線管理区域外に設 置できるなどの大きな利点がある. D $(\mathrm{D}, \mathrm{n}) \mathrm{He}$ $(\mathrm{D}=2 \mathrm{MeV})$ 反応の場合のレーザーエネルギー則を Fig. 5 (b)に示す. $1 \mathrm{~J} / 1 \mathrm{kHz}$ のレーザーで小型中性子源が でき, 現状進められているレーザー技術開発の目標の範 囲内である。装置も小型である。ただし，減速材は $2 \mathrm{MeV}$ の中性子を減速出来る大きさが必要になる。先に 揚げた $1 \mathrm{~kJ} / 1 \mathrm{~Hz}$ のレーザーができれば医療用中性子源や 産業利用への見通しもでてくる。この比例則をさらに外 挿すると，J-PARC級の $10^{17}$ 個/sを発するには， $1 \mathrm{MJ} / 1 \mathrm{~Hz}$ のレーザーが必要となる。これは，まさにレーザー核融 合炉の現在の概念設計の仕様に近いものである。これを J-PARCに比べ小型といえるかは今後のレーザー技術に よるが，この場合も放射線管理区域の問題については, レーザーは極めて有利である。いずれにしても，レー ザー核融合炉が実現すれば，それ自身が高輝度中性子源 になるので, クラスターを用いるまでもない.

また, クラスタークーロン爆発による $\mathrm{p}(\mathrm{Li}, \mathrm{n}) \mathrm{Be}$ $(\mathrm{Li}=2.25 \times 7 \mathrm{MeV})$ 反応が可能であれば(Fig. $5(\mathrm{c}))$, 

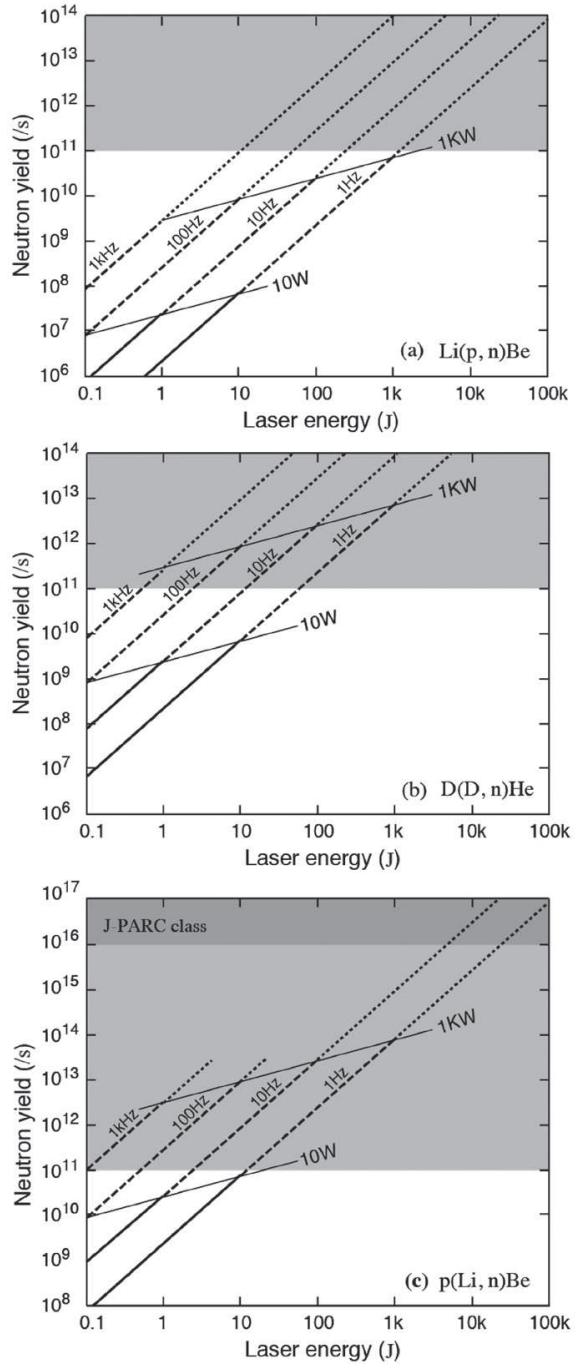

Fig. 5 Dependence of neutron yields from cluster Coulomb explosion on laser energy.

$10 \mathrm{~J} / 10 \mathrm{~Hz}$ 級の現状のレーザーでも多くの中性子を発生 でき, 中性子エネルギーも小さいので遮蔽材も小さくで き, 小型中性子源が可能となる。 また, レーザー核融合 炉にいくまでもなく，その1/10程度のレーザーエネル ギーでJ-PARC級の中性子源が可能となる。

\section{7. まとめ}

レーザーを用いた中性子源の可能性を，レーザー誘起 クラスタークーロン爆発により生成したイオンを用いた 場合について考察した。加速器ベースの中性子源と比較 する場合, レーザー装置が加速器と同程度の大きさの場 合でも，放射線管理区域を縮小できる利点がある。さら に本論文で提案しているレーザークラスター爆発方式で は, 減速材・遮蔽材の中にレーザーを直接入射する単純
な構成にでき，さらに管理区域を縮小できる，本論文で 得た発生中性子数のレーザーエネルギー比例則から, 現 在の技術で対応出来るレーザーでも小型中性子源は可能 であり，最近のレーザー技術の発展を鑑みても，医療 用，産業用の中性子源は十分に可能といえる。管理区域 を必要とする装置規模では, レーザーは加速器に比べて 有利であると考えられる。

\section{謝 辞}

本解説論文の要素となっている研究の一部は文部科学 省のグローバルCOEプログラム「普遍性と創発性から紡 ぐ次世代物理学」研究助成の支援を受けて行なわれた. 本論文の一部は，IFE-Forum主催「レーザー中性子源によ る新産業創成調査研究委員会」(委員長：井澤靖和)での 調査活動の一つとして行なったものであり，関係各位に 感謝する。また，利用観点からの中性子源と必要中性子 数についてそれぞれコメントを頂いた金谷利治氏，清 水裕彦氏に感謝する。

\section{参考文献}

1) S. Sakabe, T. Mochizuki, T. Yabe, K. Mima, and C. Yamanaka: Phys. Rev. A 26 (1982) 2159

2) 阪部周二, 飯田 敏行, 高橋亮人: 日本原子力学会誌 $\mathbf{4 3}$ (2001) 996; C. Yamanaka and S. Sakabe: Rev. Laser Eng. 30 (2002) 185.

3) M. Roth, D. Jung, K. Falk, N. Guler, O. Deppert, M. Devlin, A Favalli, J. Fernandez, D. Gautier, M. Geissel, et al.: Phys. Rev. Lett. 110 (2013) 044802.

4) T. Ditmire, T. Donnely, A. M. Rubenchik, R. W. Falcone, and M. D. Perry: Phys. Rev. A 53 (1996) 3379.

5) T. Ditmire, J. W. G. Tisch, E. Springate, M. B. Mason, N. Hay, R. A. Smith, J. Marangos, and M. H. R. Hutchinson: Nature (London) 386 (1997) 54 .

6) T. Ditmire, E. Springate, J. W. G. Tisch, Y. L. Shao, M. B. Mason, N. Hay, J. P. Marangos, and M. H. R. Hutchinson: Phys. Rev. A 57 (1998) 369.

7）レーザークラスター相互作用に関する実験の多くの論文は 9,10)の参考文献を参照.

8) S. Sakabe, M. Hashida, S. Tokita, and K. Otani: Plasma and Fusion Research 4 (2009) 041.

9) S. Sakabe, S. Shimizu, M. Hashida, F. Sato, T. Tsuyukushi, K. Nishihara, S. Okihara, T. Kagawa,Y. Izawa, K. Imasaki, et al.: Phy. Rev. A 69 (2004) 23203.

10) S. Sakabe, K. Shirai, M. Hashida, S. Shimizu, and S. Masuno: Phys. Rev. A 74 (2006) 043205.

11）西内 満美子：レーザー研究 40 (2012) 833 .

12) K. Nishihara, H. Amitani, M. Murakami, S. Bulanov, and T. Zh. Esirkepov: Nucl. Instrum. Methods Phys. Res. A 464 (2001) 98.

13) J. Zweiback, T. E. Cowan, J. H. Hartley, R. Howell, K. B. Wharton, J. K. Crane,V. P. Yanovsky, and G. Hays: Phys. Plasma 9 (2002) 3108

14) K. W. Madison, P. K. Patel, M. Allen, D. Price, R. Fitzpatrick, and T. Ditmire, Phys. Rev. A 70 (2004) 053201.

15) W. Bang, G. Dyer, H. J. Quevedo, A. C. Bernstein, E. Gaul, M. Donovan, and T. Dimire: Phys. Rev. E 87 (2013) 023106.
中性子捕捉療法 $(\mathrm{NCT}=$ Neutron capture therapy $)$

中性子捕捉療法 $(\mathrm{NCT}=$ Neutron capture therapy) は放射 線治療法の一種である。 ホウ素 $\left({ }^{10} \mathrm{~B}\right)$ と熱中性子の核反 応で生じる $\alpha$ 粒子を癌細胞に照射し破壊する「癌細胞選 択的治療法」である。発生する $\alpha$ 粒子の組織内での飛程

\section{レーザーワード}

が癌細胞一個の大きさに近く, LETが高いことから, 癌 細胞に特異的に集積するホウ素を含む化合物を用い，熱 中性子線を照射すれば癌細胞のみにエネルギーを集中し て殺傷することが可能となる. 